\title{
TRANSPARENCY OF NATIONAL BUDGET AND POVERTY REDUCTION: A CASE STUDY
}

\author{
Rubayat Jesmin
}

\author{
Independent Researcher
}

\begin{abstract}
National budget is the key document for every country indicating the country's financial health by depicting past performance and highlighting future aspirations and emphases in line with national goals and development agenda. Even two-three decades back transparent and inclusive budgeting process was considered not the right thing to do. Accordingly, national budgets were drafted and managed by the finance ministry in a cautious, non-inclusive way by leaving out civil society and other non-government actors. Now fiscal transparency is widely advocated by major international institutions such as the International Monetary Fund, the World Bank, and the Organization for Economic Co-operation and Development and practiced by most of the countries across the globe. Improved fiscal transparency has also enhanced inclusiveness. This is especially significant for developing and under-developed countries whose most important target is economic growth coupled with poverty reduction. The Open Budget Survey takes into account factors such as the amount, level of detail, and timeliness of budget information governments make publicly available to assess a country's budget transparency. This paper aims to reinstate the positive correlation between enhanced transparency of national budget and poverty reduction taking Bangladesh - a Lower Middle Income Country - as an empirical case.
\end{abstract}

Keywords: fiscal transparency, national budget, poverty reduction

\section{Introduction}

It is perceived that economic development of a country depends on well-orchestrated functioning of both the public sector and the private sector: while the private sector is the driver of economic development, the government provides facilities and the required framework (legal, regulatory, supervisory and the like) to pave the way for development. States aim to ensure economic stability as well as efficient use and full employment of resources. Therefore, it requires opting for proper and efficient collection, allocation and utilization of public finances. In this context, fiscal transparency is recognized as an essential condition of a well-functioning public sector. According to International Monetary Fund (IMF), fiscal transparency refers to the comprehensiveness, clarity, reliability, timeliness, and relevance of public reporting on the past, present, and future state of public finances. The Organization for Economic Co-operation and Development (OECD) defines fiscal transparency as openness toward the public at large about government structure and functions, fiscal policy intentions, public sector accounts, and projections. Since fiscal transparency requires providing comprehensive and reliable information about past, present, and future activities of a government including potential risks to the fiscal outlook that should result in an earlier and smoother fiscal policy response to changing economic conditions, the availability of such information helps to improve the quality of economic policy decisions and reduces the incidence and severity of crises. On the other hand, by defining the scope and responsibilities of the government in a clear manner, making available the fiscal information (both revenue and expenditure) for the population, openly preparing and executing the budget, and assuring the integrity of fiscal procedures, a transparent fiscal environment limits corruption and diversion and, therefore, facilitates development and the increase in living standards. Hence, fiscal transparency helps to provide a government the exact picture about public finances including costs and benefits of a policy continuation or policy change as well as the associated risks, which, in 
turn, helps a government in assessing and adopting policy decisions. Additionally, fiscal transparency benefits citizens by giving them the information they need to hold their government accountable for its policy choices. Thus, financial transparency is critical not only for effective fiscal management but also for accountability. The transparent governments also benefit from improved access to international capital markets. The greater oversight by civil society and international markets further reinforces the first objective by encouraging governments to pursue sound economic policies and achieve greater financial stability.

Budget transparency is considered to be one of the most crucial elements of fiscal transparency as this enhances accountability by providing clarity about the sources and uses of public funds which, in turn, ensures public representatives' and officials' accountability for effectiveness and efficiency; - improves integrity and reduces scope of in the use of public funds; - augments inclusiveness by involving informed and inclusive debate about the budget policy impacts; - fosters trust in society that people's views and interests are respected and that public money is used well; and ultimately, supports better fiscal outcomes and more responsive, impactful and equitable public policies.

This paper aims to revisit the correlation between fiscal transparency, more specifically budget transparency, and government's poverty reduction initiatives in Bangladesh. Over the last decade, the country has enjoyed accelerated economic growth along with remarkable progress in socio-economic sector despite numerous internal and external challenges such as wide-spread poverty, effects of climate change, global slowdown, and so on. To combat these challenges in order to maintain the growth momentum coupled with poverty alleviation, the Government of Bangladesh has adopted and implemented numerous reforms to strengthen its public financial management systems. This paper will assess how fiscal transparency has played a role, if any, in the country's poverty reduction which happened in many countries around the world.

\section{Fiscal Transparency and Economic Performance}

It is now generally accepted that fiscal transparency is a core element of good governance, which, in turn, is of grave importance for achieving macroeconomic stability and high-quality growth. To assess a country's state of fiscal transparency the IMF in 1998 introduced a Code of Good Practices on Fiscal Transparency, which is now recognized as the international standard for disclosure of information about public finances. Following this Code countries conduct a voluntary program of fiscal transparency assessments called fiscal transparency modules of Reports on the Observance of Standards and Codes (fiscal ROSCs). The IMF's Code of Good Practices on Fiscal Transparency comprises of a set of principles built around four pillars: (i) clarity of roles and responsibilities of the government; (ii) open budget process; (iii) public availability of information; and (iv) assurances of integrity. Briefly,

- the First Principle advocates that the government sector should be distinguished from the rest of the public sector and from the rest of the economy, and policy and management roles within the public sector should be clear and publicly disclosed. Simultaneously, it is required that there should be a clear and open legal, regulatory, and administrative framework for fiscal management. Accordingly, the first principle assesses the extent to which the non-commercial activities of the government are clearly distinguished from the rest of the economy; how clearly defined are the responsibilities of the executive, legislative and judicial branches; how the budgetary and extra-budgetary activities are coordinated and managed; how clear are the arrangements between the government and nongovernment public agencies; how clear and nondiscriminatory is the government involvement in the private sector; how open and comprehensive are the budget laws defining the commitment and administrative rules; how explicit, easily accessible and understandable is the legal framework for revenue management including that for taxation and other public financial issues; how well are the contractual arrangements between the government and public or private entities; and clarity on government liability and asset management mechanism. 
- the Second Principle stresses that budget preparation should follow an established timetable and be guided by well-defined macroeconomic and fiscal policy objectives and that there should be clear procedures for budget execution, monitoring, and reporting. This principle also upholds that audited final accounts and audit reports, including reconciliation with the approved budget, should be presented to the legislature and published within a year.

- the Third Principle advocates that the public should be provided with comprehensive information on past, current, and projected fiscal activity and on major fiscal risks. In addition, fiscal information should be presented in a way that facilitates policy analysis and promotes accountability. To ensure public availability of fiscal information, the third principle also states that the timely publication of fiscal information should be a legal obligation of government.

- to ensure integrity, the Fourth Principle stresses on the importance of fiscal data meeting the accepted data quality standards and to be subject to effective internal oversight and safeguards as well as to be scrutinized externally.

Countries are now more and more encouraged in promoting fiscal transparency following the inception of the Code. A number of other transparency initiatives in the fiscal area have also been established over the years, including the OECD best practices for budget transparency (issued in 2001), the multi-stakeholder Extractive Industries Transparency Initiative (EITI - launched in 2002), and the Open Budget Index by the Open Budget Initiative (introduced in 2005). In addition, for countries in receipt of official development assistance, assessments under the multi-donor Public Expenditure and Financial Accountability (PEFA) program include a series of performance indicators covering aspects of fiscal transparency, crucial for effective public financial management (PFM), which are derived in part from the Code. The Code has also been used by the private sector as a framework for evaluating fiscal transparency.

Numerous studies aimed to assess the contribution of fiscal transparency in a country's economic performance and its aspiration to alleviate poverty. After conducting comparable fiscal incidence analysis for 28 low and middle income countries, Lustig (2017) highlights that fiscal policy plays a positive role in reducing inequality, but, to varying degrees, in all countries a portion of the poor are net payers into the fiscal system and are thus impoverished by the fiscal system because of various consumption taxes. While spending on pre-school and primary school is pro-poor (i.e., the per capita transfer declines with income) in almost all countries, pro-poor secondary school spending is less prevalent, and tertiary education spending tends to be progressive only in relative terms (i.e., equalizing but not pro-poor). Health spending is always equalizing but not always pro-poor. In addition, Ali, Lustig, and Aranda (2017) and Ali (2017) shows that the redistributive potential of a country does indeed depend on the size and composition of government spending and how it is financed, as well as the progressivity of all the taxes and government spending combined.

On the other hand, based on assessments of fiscal transparency in twelve countries in Latin America, Parry (2007) shows that good fiscal management and improvements in fiscal transparency enhance the prospect for sound fiscal performance and a more favorable investment environment. This is an important step toward sustaining stable, higher quality growth which, ultimately, contributes to poverty reduction.

The development and implementation of MTBF has proved to be an effective tool for enhancing fiscal transparency. To develop a MTBF, governments need to involve their spending ministries in developing detailed medium-term estimates, which then be reviewed as part of the annual budget process and included in the budget document. As the quality of forward estimates improves, they can serve as the basis for the following years' annual budget to deepen the connection between forward-year plans and the annual budget preparation process. The medium term budget then becomes a credible statement of fiscal policy intentions and a means to avoid pro-cyclical fiscal policy. Accordingly, the MTBF is also recognized as a valuable tool for planning reallocation of expenditure toward pro-poor programs. 
In order to ascertain budget transparency to the citizens, the government should provide clear information, on a regular basis, at least on the programs, objectives, responsible agency, targets/indicators set along with the timeframe, budget allocation, financial performance and gaps/risks-faced. This will enable the public to assess the performance of government's past, current and projected fiscal activities (also in terms of sources and uses of funds) and associated fiscal risks.

\section{Bangladesh - country context}

Bangladesh has come a long way from being an aid dependent country soon after its independence in 1971 to today's export-led Lower Middle Income Country according to the World Bank classification. As per the official statistics, the country achieved a record economic growth of 7.28 percent in Fiscal Year 2016 - 2017 (in Bangladesh, Fiscal Year - FY - covers the period from July to June next year; i.e. Fiscal Year 2016 - 2017 refers to July 2016 to June 2017). At the same time, Gross National Income (GNI) per capita has grown US\$1,602 (current prices) which was around US\$ 100 only in 1972. The country also attained most of the targets of Millennium Development Goals (MDGs) and set an example for other developing countries. Bangladesh achieved notable progress in poverty reduction, gender parity in primary and secondary schools, enrollment rate in primary schools, reduction of maternal, infant and under-\% mortality, expansion of immunization coverage, women empowerment, etc. The country is now in Medium Human Development group in Human Development Index. Despite these progresses, disparities across economic classes, social groups, gender and regions continue.

Table 1: Selected Economic Indicators (Bangladesh)

\begin{tabular}{|c|c|c|c|c|c|c|c|c|c|c|}
\hline Indicators & FY08 & FY09 & FY10 & FY11 & FY12 & FY13 & FY14 & FY15 & FY16 & FY17 \\
\hline $\begin{array}{l}\text { GDP growth (at FY06 } \\
\text { constant market prices) }\end{array}$ & 6.0 & 5.1 & 5.6 & 6.5 & 6.5 & 6.0 & 6.1 & 6.6 & 7.1 & 7.28 \\
\hline $\begin{array}{l}\text { CPI inflation (base: } \\
\text { FY96=100) }\end{array}$ & 9.9 & 6.7 & 7.3 & 8.8 & 8.7 & 6.8 & 7.4 & 6.4 & 5.9 & 5.4 \\
\hline $\begin{array}{l}\text { Foreign exchange } \\
\text { reserves (billion US\$) }\end{array}$ & 6.15 & 7.47 & 10.75 & 10.91 & 10.36 & 15.32 & 21.51 & 25.03 & 23.62 & 25.52 \\
\hline Population (million) & 143.8 & 145.8 & 147.8 & 149.7 & 151.6 & 153.7 & 155.8 & 157.9 & 159.9 & 161.8 \\
\hline \multicolumn{11}{|l|}{ (As percentage of GDP) } \\
\hline Domestic savings & 19.2 & 20.3 & 20.8 & 20.6 & 21.2 & 22.0 & 22.1 & 22.2 & 25.0 & 26.1 \\
\hline Investment & 26.2 & 26.2 & 26.3 & 27.4 & 28.3 & 28.4 & 28.6 & 28.9 & 29.7 & 30.3 \\
\hline Revenue income & 9.6 & 9.1 & 9.5 & 10.2 & 10.9 & 10.7 & 10.5 & 9.6 & 10.2 & 12.4 \\
\hline Total expenditures & 14.9 & 12.5 & 12.7 & 14.0 & 14.5 & 14.5 & 14.0 & 13.5 & 15.3 & 17.4 \\
\hline Export & 15.4 & 15.2 & 14.1 & 17.6 & 18.0 & 17.7 & 17.2 & 15.8 & 15.1 & 9.0 \\
\hline Import & 21.3 & 19.8 & 18.6 & 25.3 & 25.0 & 22.4 & 21.2 & 18.8 & 17.9 & 11.4 \\
\hline
\end{tabular}

Source: Bangladesh Economic Review 2017, Ministry of Finance (https://mof.gov.bd/en/)

To achieve enhanced inclusive growth and sustainable development contributing to poverty reduction, the country needs to pave the way for further socio-economic development of disadvantaged and vulnerable groups specially, women, children, indigenous people and other backward sections of the society. To realize its goals of attaining a Middle-Income Country status by 2021, the Government of Bangladesh, in its national development documents (e.g. Outline Perspective Plan of Bangladesh 2010-2021: Making Vision 2021 a Reality, and the $7^{\text {th }}$ Five Year Plan 2016-2020), has acknowledged the need and importance for a strengthened revenue collection mechanism and a prudent spending of resources for better public services delivery, improvement of the efficiency and productivity of public sector enterprises and of the financial governance. This calls for mitigation 
of key governance challenges such as low public administration capacity, weaknesses in public order and safety and in economic management. Enhanced fiscal transparency through a sound public financial management (PFM) system can significantly contribute in this regard by addressing issues related to revenue mobilization, allocation of funds to various activities in line with the policies, efficient expenditure, proper accounting, and effective scrutiny and oversight of the spent funds.

\section{Fiscal Transparency in Bangladesh: an analysis}

\section{Key Public Institutions}

The Ministry of Finance (MoF) is the primary fiscal transparency and PFM stakeholder who is responsible for preparation, execution and presentation of the budgets and government financial statements to the Parliament. National Board of Revenue (NBR), under jurisdiction of the MoF, is the apex authority for tax administration with the primary responsibility for the formulation and re-appraisal of tax-policies and tax-laws, negotiating tax treaties with foreign governments and the collection of tax revenues (mainly, Income Tax, Value Added Tax, Customs Duty and Excise Duty). The Planning Commission prepares the development part (around 30 percent) of the budget and the national development documents such as Perspective Plan and Five Year Plans. It is the primary body responsible for planning in Bangladesh. The National Economic Council (NEC) provides overall guidance at the stage of the formulation of Five Year Plans, Annual Development Programs (ADP) and other economic policies. It reviews progress of implementation of development programs and approves development projects. The ADPs are endorsed by the Executive Committee of NEC (ECNEC) throughout the year in the monthly meetings. The Cabinet is responsible for approval of the budget within the Government before its presentation to the Parliament. Individual Ministers are responsible for line ministry policies, programs and budgets. The Coordination Council coordinates the macroeconomic framework including fiscal, monetary and exchange rate strategies and policies. The Budget Management and Review Committee assess the availability of resources and discuss progress on budget implementation. This Committee of senior civil servants from central Ministries/ Divisions is headed by the Finance Minister. Line Ministries and Divisions are responsible for providing key inputs to the budget process in the form of MTBF and development proposals. They are the recipients of the budget allocations, and responsible for the delivery of programs and projects.

On the other side, the Office of the Comptroller and Auditor General (OCAG), the Supreme Audit Institution (SAI) of Bangladesh, is responsible for auditing government receipts and public spending. The Parliament and its three financial oversight committees - Public Accounts Committee (PAC), Estimates Committee and Undertaking Committee - play a major role in promoting public sector accountability and effective governance. In addition, the Standing Committee on Ministry of Finance is responsible for overviewing the activities and performance of the Ministry of Finance in the areas of public finance including national budget, taxation and economic policy.

\section{Main Instruments}

Following this, several instruments guide Bangladesh Government's implementation activities for achieving the planned social and economic development embedded in its Five Year Plans. The Annual Development Program (ADP) is the main document that covers all public investment in Bangladesh. The Medium-Term Budget Framework (MTBF) is the fiscal arrangement that allows the Government to extend the timeframe for fiscal policy making beyond the annual budgetary calendar. The introduction of the MTBF approach of budgeting in the country in FY2005-06 was a milestone in the context of fostering fiscal transparency in Bangladesh. It covers the preparation, execution, and monitoring of multi annual budget plans and contain both expenditure and revenue projections as well as the resultant budget balances. The underlying objectives of this approach are: establish aggregate fiscal discipline, enhance allocative efficiency, provide advance information on resource availability over the medium-term, enhance resource utilization capacity and establish an institutional arrangement on financial accountability. It demands that during the budget preparation, ministries should 
attach more importance on the deliverables (goods and services) and achievements (output and outcome) than on resource allocation. That is, more emphasis needs to be given on the output expected to be achieved in the short-term, and outcome/impact expected to be created on the socio-economic field over the medium to longterm through utilization of allocated resources. The Government of Bangladesh has also introduced the Medium Term Strategy and Business Plan, which is the budgetary instrument to link the Five Year Plan and sector strategies to the policies and budgets at the individual ministry level. The Annual Operational Plan - prepared within the framework of the MTSBP - aims at allocating adequate resources against specific projects and activities. On the other hand, the Annual Performance Agreements (APA) is used as a monitoring and evaluation instrument within the Government Performance Monitoring System to assess each ministry's performance against a specific set of indicators, including in public financial sector.

\section{Reforms - past and ongoing}

With respect to the fiscal transparency improvement and financial governance development processes, a series of PFM reform programs were undertaken from the 1990s onwards. The past reforms followed a gradualist approach in two distinct phases. The first phase for PFM reform can be dated back to 1989 when the Committee on Reforms in Budgeting and Expenditure Control (CORBEC) provided findings and recommendations on the PFM improvement which were the basis of the initial PFM reform projects that addressed basic technical issues such as budget classification, core financial rules and the introduction of basic information technology in budgeting and accounting functions. These reforms undoubtedly improved the management of public resources, but fell short of expectations as some of such initiatives (e.g. the development of a new chart of accounts or the roll out of a new Financial Management Information System), though improving, are yet to make a significant difference. The second phase, characterized by the development of broad reform programs, focused on more strategic and advanced reforms such as the introduction of the Medium-Term Budget Framework (MTBF), enhanced systems through the introduction of the Integrated Budgeting and Accounting System (iBAS), strengthened debt management, macro-economic forecasting, an updated budget classification system and enhanced cash forecasting and management, introduction of ASYCUDA (an now ASYCUDA WORLD) and external scrutiny and oversight. However some of these reforms, such as the development of a medium-term horizon when preparing budgets, as well as strengthening the linkages between budgets and policies, are still struggling to be fully operational across all ministries.

Briefly, since the nineties the core PFM reforms have been put in place contributing to the achievement of the Government's vision to:

- Enhance revenue collection by identifying new taxpayers alongside addressing loopholes in the system (such as tax evasion, tax exemptions, etc.) and, thus, increasing the revenue-GDP ratio

- Improve the budgeting, accounting and expenditure control procedures

- Establish a financial management information system

- Improve the management of public debt, deficits, local currency loans etc.

- Improve the links between the Revenue and Development budgets

- Establish links between budget and macro-economic policy

- Introduce modern budgeting techniques like program-based budgets

- Improve the capacity of government officers in PFM

- Update and modernize the manuals and codes

\section{Status of Fiscal Transparency}

On the basis of IMF's Code of Good Practices on Fiscal Transparency, Bangladesh's status is depicted below. 
Table 2: Status of Fiscal Transparency in Bangladesh

\begin{tabular}{|c|c|c|}
\hline IMF's Principles & Basic Requirements & Bangladesh's status \\
\hline \multicolumn{3}{|c|}{ Clarity of Roles and Responsibilities } \\
\hline \multirow{3}{*}{$\begin{array}{l}\text { 1.1 The government } \\
\text { sector should be } \\
\text { distinguished from the } \\
\text { rest of the public sector } \\
\text { and from the rest of the } \\
\text { economy, and policy and } \\
\text { management roles within } \\
\text { the public sector should } \\
\text { be clear and publicly } \\
\text { disclosed. }\end{array}$} & $\begin{array}{l}\text { A published institutional table clearly } \\
\text { shows the structure of the public } \\
\text { sector, identifying all government } \\
\text { entities, by level of government, and } \\
\text { public corporations. }\end{array}$ & $\begin{array}{l}\text { The Government website } \\
\text { (http://www.bangladesh.gov.bd//) contains } \\
\text { information on all government entities } \\
\text { including public corporations. }\end{array}$ \\
\hline & $\begin{array}{l}\text { The extent and purpose of all quasi- } \\
\text { fiscal activities is explained. }\end{array}$ & $\begin{array}{l}\text { Quasi-fiscal activities are not always } \\
\text { explained. }\end{array}$ \\
\hline & $\begin{array}{l}\text { Revenue and responsibilities are } \\
\text { clearly assigned between different } \\
\text { levels of government. }\end{array}$ & $\begin{array}{l}\text { The Government website } \\
\text { (http://www.bangladesh.gov.bd/), } \\
\text { respective line ministry's website and } \\
\text { national budget documents contain such } \\
\text { information }\end{array}$ \\
\hline \multirow{2}{*}{$\begin{array}{l}1.2 \text { There should be a } \\
\text { clear and open legal, } \\
\text { regulatory, and } \\
\text { administrative } \\
\text { framework for fiscal } \\
\text { management. }\end{array}$} & $\begin{array}{l}\text { No public funds can be spent without } \\
\text { publicly available evidence of } \\
\text { appropriation by the legislature. }\end{array}$ & This is established by the Constitution. \\
\hline & $\begin{array}{l}\text { Revenue collection is governed by } \\
\text { clear and easily accessible laws and } \\
\text { regulations. }\end{array}$ & $\begin{array}{l}\text { Required laws and regulations are in place; } \\
\text { but tax evasion, tax exemption and less } \\
\text { number of tax payers contribute to low tax- } \\
\text { GDP ratio. }\end{array}$ \\
\hline \multicolumn{3}{|l|}{ Open Budget Processes } \\
\hline \multirow{3}{*}{$\begin{array}{l}2.1 \text { Budget preparation } \\
\text { should follow an } \\
\text { established timetable and } \\
\text { be guided by well- } \\
\text { defined macroeconomic } \\
\text { and fiscal policy } \\
\text { objectives. }\end{array}$} & $\begin{array}{l}\text { Realistic draft budget proposals are } \\
\text { presented to the legislature according } \\
\text { to a prescribed timetable. }\end{array}$ & $\begin{array}{l}\text { Budget proposals are prepared on a timely } \\
\text { manner. }\end{array}$ \\
\hline & $\begin{array}{l}\text { The likely costs and effects of new } \\
\text { expenditure and revenue measures } \\
\text { are clearly explained. }\end{array}$ & This is not always done properly. \\
\hline & $\begin{array}{l}\text { A consistent multiyear fiscal } \\
\text { framework is provided, based on } \\
\text { realistic economic assumptions. }\end{array}$ & $\begin{array}{l}\text { MTBF is prepared regularly. But there is } \\
\text { room for improvement in case of making } \\
\text { realistic economic assumptions. }\end{array}$ \\
\hline \multirow{2}{*}{$\begin{array}{l}2.2 \text { There should be clear } \\
\text { procedures for budget } \\
\text { execution, monitoring, } \\
\text { and reporting. }\end{array}$} & $\begin{array}{l}\text { Revenues, commitments, payments, } \\
\text { and arrears can be tracked } \\
\text { effectively. }\end{array}$ & $\begin{array}{l}\text { Many issues in these areas need further } \\
\text { attention and reform. }\end{array}$ \\
\hline & $\begin{array}{l}\text { Audited final accounts and audit } \\
\text { reports are presented to the } \\
\text { legislature and published within a } \\
\text { year. }\end{array}$ & $\begin{array}{l}\text { There is considerable time lag in preparing } \\
\text { audited final accounts and audit reports, } \\
\text { placing those before the legislature and } \\
\text { publishing within a year. }\end{array}$ \\
\hline \multicolumn{3}{|c|}{ Public Availability of Information } \\
\hline \multirow[t]{2}{*}{$\begin{array}{l}3.1 \text { The public should be } \\
\text { provided with } \\
\text { comprehensive } \\
\text { information on past, } \\
\text { current, and projected } \\
\text { fiscal activity, and on } \\
\text { major fiscal risks. }\end{array}$} & $\begin{array}{l}\text { The budget documentation covers all } \\
\text { budgetary and extra-budgetary } \\
\text { activities of the central government, } \\
\text { the fiscal position of subnational } \\
\text { government, and the finances of } \\
\text { public corporations. }\end{array}$ & $\begin{array}{l}\text { The budget document is very } \\
\text { comprehensive. The documents can be } \\
\text { made more reader-friendly so that } \\
\text { information on past, current and projected } \\
\text { fiscal activities - also in terms of sources } \\
\text { and uses of funds - can be tracked easily. }\end{array}$ \\
\hline & $\begin{array}{l}\text { Information published on the central } \\
\text { government includes details of its } \\
\text { debt, significant financial and natural } \\
\text { resource assets and non-debt } \\
\text { liabilities, and contingent liabilities. }\end{array}$ & $\begin{array}{l}\text { Information published on the central } \\
\text { government includes details on many } \\
\text { aspects, but there is less clarity on } \\
\text { information regarding financial and natural } \\
\text { resource assets, non-debt liabilities, etc. }\end{array}$ \\
\hline $\begin{array}{l}3.2 \text { Fiscal information } \\
\text { should be presented in a }\end{array}$ & $\begin{array}{l}\text { The main proposals and economic } \\
\text { background to the budget are }\end{array}$ & $\begin{array}{l}\text { In recent times, Government encourages } \\
\text { pre-budget consultations even with general }\end{array}$ \\
\hline
\end{tabular}




\begin{tabular}{|c|c|c|}
\hline IMF's Principles & Basic Requirements & Bangladesh's status \\
\hline \multirow{3}{*}{$\begin{array}{l}\text { way that facilitates } \\
\text { policy analysis and } \\
\text { promotes accountability. }\end{array}$} & $\begin{array}{l}\text { explained clearly to the general } \\
\text { public. }\end{array}$ & $\begin{array}{l}\text { people. There are some limited numbers of } \\
\text { post-budget discussions as well. }\end{array}$ \\
\hline & $\begin{array}{l}\text { Revenue, expenditure, and financing } \\
\text { are reported on a gross basis and } \\
\text { expenditure is classified by } \\
\text { economic, functional, and } \\
\text { administrative category. }\end{array}$ & $\begin{array}{l}\text { It is done along with the other budget } \\
\text { documents. But there is a gap in reporting } \\
\text { and accounting of revenue collection. In } \\
\text { addition, expenditure is still not classified } \\
\text { by economic and functional category. }\end{array}$ \\
\hline & $\begin{array}{l}\text { Results of central government } \\
\text { programs are presented to the } \\
\text { legislature. }\end{array}$ & This is done on an ad-hoc basis. \\
\hline $\begin{array}{l}3.3 \text { A commitment } \\
\text { should be made to the } \\
\text { timely publication of } \\
\text { fiscal information. }\end{array}$ & $\begin{array}{l}\text { There is a legal obligation to publish } \\
\text { timely }\end{array}$ & Commitment is there. \\
\hline \multicolumn{3}{|l|}{ Assurances of Integrity } \\
\hline \multirow{3}{*}{$\begin{array}{l}\text { 4.1 Fiscal data should } \\
\text { meet accepted data } \\
\text { quality standards. }\end{array}$} & $\begin{array}{l}\text { Accounting policies meet generally } \\
\text { accepted accounting standards. }\end{array}$ & $\begin{array}{l}\text { Weaknesses are observed in this area. } \\
\text { Further improvement is needed. }\end{array}$ \\
\hline & $\begin{array}{l}\text { Final accounts are fully reconciled } \\
\text { with budget appropriations and fiscal } \\
\text { aggregate outcomes are compared } \\
\text { with previous forecasts. }\end{array}$ & $\begin{array}{l}\text { Sometimes there is a time lag. Further } \\
\text { improvement is needed in this area. }\end{array}$ \\
\hline & $\begin{array}{l}\text { Countries subscribe to General Data } \\
\text { Dissemination System (GDDS) if } \\
\text { they are not able to adhere to SDDS }\end{array}$ & $\begin{array}{l}\text { The country is the process of developing } \\
\text { Special Data Dissemination Standards } \\
\text { (SDDS). }\end{array}$ \\
\hline \multirow[t]{2}{*}{$\begin{array}{l}\text { 4.2 Fiscal activities } \\
\text { should be subject to } \\
\text { effective internal } \\
\text { oversight and safeguards. }\end{array}$} & $\begin{array}{l}\text { Standards for procurement, financial } \\
\text { transactions involving the public } \\
\text { sector, and the ethical behavior of } \\
\text { public servants are clear, publicly } \\
\text { accessible, and observed. }\end{array}$ & $\begin{array}{l}\text { The standards are there, but there are issues } \\
\text { in terms of implementation. }\end{array}$ \\
\hline & Internal audit procedures are clear. & $\begin{array}{l}\text { Internal control mechanism needs to be } \\
\text { effectively introduced across the } \\
\text { government entities. }\end{array}$ \\
\hline $\begin{array}{l}4.3 \text { Fiscal information } \\
\text { should be externally } \\
\text { scrutinized. }\end{array}$ & $\begin{array}{l}\text { A national audit body, which is } \\
\text { independent of the executive, } \\
\text { provides timely reports (at a } \\
\text { minimum on an annual basis) for the } \\
\text { legislature and public on the financial } \\
\text { integrity of government accounts. }\end{array}$ & $\begin{array}{l}\text { There is considerable time lag in preparing } \\
\text { audit reports. }\end{array}$ \\
\hline
\end{tabular}

Source: IMF's Manual on Fiscal Transparency and Researcher's own assessment

The Public Expenditure and Financial Accountability (PEFA) Assessment 2015 for Bangladesh confirms the above findings. The PEFA 2015 highlights progress in areas such as medium-term budgeting, macro-economic forecasting, debt management, fiscal transparency, improved financial information management and in external auditing. It also points out that deficiencies remain notably in the accounting, financial management information system, in the fragmentation of the recurrent and development budgets, in budget transparency, timeliness and quality of the annual audited financial statement as well as in internal controls, external oversight mechanism, follow-up to audit observations and on the revenue collection and tax administration. It needs also to be aware that in some areas reforms are only just starting and are yet to see results. For instance, advanced reforms of the tax administration and public investment management are only just getting off the ground.

The Open Budget Index evaluates the quantity of information provided to citizens in the eight key budget documents that all governments should make public during the course of the budget year. The executive's 
budget proposal is one of the most important documents released during the budget year. Bangladesh's executive's budget proposal provides some information to the public on a comprehensive picture of the government's financial activity, but there is room for improvement. For better budget transparency, it is required that governments should report to citizens regularly during the budget year on their spending, revenue collection and borrowing with in-year reports. Bangladesh provides partial information in its in-year reports, but it would greatly strengthen public accountability by publishing a comprehensive mid-year review. This document should provide the public with updates on what can be expected for the second half of the budget year. Year-end reports by the executive are also not produced regularly which impedes comparisons between enacted levels and actual outcomes. Bangladesh does not make its audit report public on time and does not provide any information on whether the audit report's recommendations are successfully implemented. Citizens require both access to information, and opportunities during the consideration of the budget to use that information, to ensure their informed participation in budget debates as well as to hold the government accountable for its management of the public's money. Hence, Bangladesh's score on the Open Budget Index over the years suggests that the public's access to information has to be improved. To improve budget transparency, the country should publish In-Year Reports in a timely manner, and produce and publish an Audit Report and a Citizens Budget.

Table 3: Bangladesh's ranking in Open Budget Index

\begin{tabular}{|l|l|l|l|l|}
\hline Parameters & 2006 & 2012 & 2015 & 2016 \\
\hline Pre -budget statement & $\begin{array}{l}\text { Produced for } \\
\text { Internal Use Only }\end{array}$ & $\begin{array}{l}\text { Produced for } \\
\text { Internal Use Only }\end{array}$ & $\begin{array}{l}\text { Produced for } \\
\text { Internal Use Only }\end{array}$ & $\begin{array}{l}\text { Produced for } \\
\text { Internal Use Only }\end{array}$ \\
\hline $\begin{array}{l}\text { Executive's budget } \\
\text { proposal }\end{array}$ & $\begin{array}{l}\text { Available to the } \\
\text { public }\end{array}$ & $\begin{array}{l}\text { Available to the } \\
\text { public }\end{array}$ & $\begin{array}{l}\text { Available to the } \\
\text { public }\end{array}$ & $\begin{array}{l}\text { Available to the } \\
\text { public }\end{array}$ \\
\hline Enacted budget & $\begin{array}{l}\text { Available to the } \\
\text { Public }\end{array}$ & $\begin{array}{l}\text { Available to the } \\
\text { public }\end{array}$ & $\begin{array}{l}\text { Available to the } \\
\text { Public }\end{array}$ & $\begin{array}{l}\text { Available to the } \\
\text { Public }\end{array}$ \\
\hline Citizen's Budget & Not produced & Not produced & $\begin{array}{l}\text { Available to the } \\
\text { Public }\end{array}$ & Not produced \\
\hline In-year reports & $\begin{array}{l}\text { Available to the } \\
\text { public }\end{array}$ & $\begin{array}{l}\text { Available to the } \\
\text { Public }\end{array}$ & $\begin{array}{l}\text { Available to the } \\
\text { Public }\end{array}$ & Produced late \\
\hline Mid-year review & $\begin{array}{l}\text { Produced for } \\
\text { Internal Use Only }\end{array}$ & $\begin{array}{l}\text { Available to the } \\
\text { Public }\end{array}$ & $\begin{array}{l}\text { Available to the } \\
\text { Public }\end{array}$ & Not produced \\
\hline Year-end report & Not produced & Not produced & $\begin{array}{l}\text { Available to the } \\
\text { Public }\end{array}$ & $\begin{array}{l}\text { Available to the } \\
\text { Public }\end{array}$ \\
\hline Auditor's reports & $\begin{array}{l}\text { Produced, but for } \\
\text { internal use only }\end{array}$ & Not produced & Not produced & Not produced \\
\hline Ranking (out of 100) & 39 & 58 & 56 & 56 \\
\hline
\end{tabular}

Source: compiled from different Open Budget Indices published by the International Budget Partnership

\section{Challenges faced}

The reforms undertaken (and planned) in the area of Bangladesh's PFM system has been part of a broader political agenda of poverty reduction and were based on the understanding that promoting transparency and accountability in the management of public resources is essential in spearheading and sustaining the government's efforts in reducing poverty. Nevertheless, it is not clear to what extent politicians really understand and believe in the value of fiscal openness, and this undermines reform success. In addition, Ministry of Finance continues to spearhead the reforms related to fiscal transparency when line ministries and other government agencies have a critical role to play in promoting transparency in the use of public funds. Furthermore, every year revenue collection falls short of the target set in the national budget. The national budget also does not outline potential sources of revenue to back up the additional revenue target. In order to enriching the Government exchequer and meeting incremental expenditure budget, the internal resource 
planning, NBR Tax, and non-NBR revenue sources should be redesigned making those more realistic for attaining the ambitious revenue collection target. Failure to realize expected tax collection hamper the regular government expenditure and ADP implementation and result in mid-year revision (mostly downsizing) of the budget. This, undoubtedly, impacts the planning and effectiveness of public financing and the rational mobilization of resources. On the other hand, the promotion of fiscal transparency has been mostly supplydriven. External actors have played a positive role in recent times, both in setting norms and standards and in providing support to - and putting pressure on - the Government to become more transparent. Fiscal transparency should be linked to demand for budget accountability and, ultimately, to improved access and quality of basic public services. In this context, both institutional and human resource capacities need to be improved further.

\section{Budget Transparency and Poverty Reduction - the correlation in Bangladesh's context}

For achieving most of the MDGs and attaining more than 6 percent growth rate for several consecutive years, Bangladesh is now considered to be a model for other developing countries. Poverty reduction remains at center of Government's development agenda. The economic growth strategy of Government's, the $7^{\text {th }}$ Five Year Plan, is based on four fundamental themes:

- Break out of the sphere of $6 \%$ growth and raise the annual average growth rate to $7.4 \%$

- Growth will be inclusive, pro-poor, adapt well to the urban transition and be environmentally sustainable

- By the end of the $7^{\text {th }}$ Five Year Plan (i.e. by FY 2020), poverty and extreme poverty will be substantially lowered

- All the additional labor force will be gainfully employed including much of the under-employed

Official data indicates that both national poverty rate and extreme poverty rate are on downward trend. Annual national poverty rate and extreme poverty rate in Bangladesh now stands at 23.2 percent and 12.9 percent, respectively (Household Income and Expenditure Survey - HIES, 2016). In 2010, national poverty rate stood at 31.5 percent and extreme poverty rate at 18.5 percent (HIES, 2010). In 2005, national poverty rate was 40 percent (Bangladesh Poverty Maps, 2005). Though the poverty rate is decreasing in the country, the pace of poverty reduction has slowed down in recent years compared with the period 2005-2010.

On the other hand, the national Gini co-efficient shows a negative trend in income and wealth distribution. According to HIES 2016, the Gini co-efficient now stands at 0.483 , while it stood at 0.458 in 2010 . That is, due to unequal distribution of income, income gap is getting wider between rich and poor.

There also exists a regional disparity: poverty rate is the highest in rural areas, at 36 percent, compared with 28 percent in urban area. In addition, the incidences of poverty are higher in some part of the country compared to those advanced part such as Dhaka and Chittagong.

To address these issues and to attain national development goals, the Government of Bangladesh has been meticulously tracking poverty reduction related government-initiated activities and associated expenditures since FY2007-2008. In order to attain the objective of poverty reduction, the country's Ministry of Finance has grouped areas of spending in a way to generate a better focus in terms of priority on programs/spending that would benefit the poor, such as: direct services, and indirect services. The Direct (targeted) Services addressing income-poverty includes social safety net programs, income and employment generating programs/projects targeted directly at the poor, i.e. the services that benefit the poor for the most part. Direct services are designed and targeted at the poor and, hence easy to identify and prioritize. However, some activities in this category, though targeted at the poor may not always reach the 'hard-core' poor. Micro-credit programs are examples in hand. Social 'safety nets' and other income and employment generating programs are good examples of direct 
services to address income-poverty. The other types of direct services help human development, and hence mitigate human-poverty. Programs/projects for development of education (primary, secondary, technical/vocational, etc.), health, nutrition, and water and sanitation are good examples of direct services addressing human poverty. The Indirect (growth-oriented) Services include spending on overall infrastructure development including roads/highways, electrification, modern agriculture etc. These services are not directly pro-poor in appearance but, rather pro-growth in nature. Some of these services, however, contribute to the alleviation of poverty more than the others. For example, construction of the road/highway does help all, regardless of the income-class and certainly is pro-growth. Since most of these indirect services are growthoriented, they help alleviate income-poverty, e.g. spending for building roads and highways, bridges construction/repair/rehabilitation of river ports/terminals etc. Some of the indirect services help alleviate human-poverty, e.g. spending on construction, repair/renovation of primary/secondary schools flood rehabilitation, etc.

Bangladesh recognized decades ago that empowering women and creation of human capital are essential to ending extreme poverty. In this context, the country introduced and implemented various innovative approaches. For instance, Bangladesh developed a national family planning program in the 1980s that created an army of women health workers who went door to door to bring contraceptives to women. This helped reduce fertility rates dramatically and sparked the demographic transition that continues to support remarkable development progress. The following decade, in the 1990s, Bangladesh started a female secondary school stipend program, one of the first conditional cash transfers programs in the world. To track the activities and associated spending, the Government of Bangladesh has introduced Gender Budget since FY2007-2008 and Child Budget since FY2014-FY2015 derived from MTBFs of respective line ministries and divisions.

\section{Conclusion}

It is widely acknowledged that fiscal policy is a powerful tool for combating poverty. In the short term, governments provide cash transfers, food relief, and subsidies. In the medium and long term, they opt for improving education and health services and create regulatory and institutional framework for employment generation. Domestic revenue mobilization such as taxes is the main source for these activities. Hence, governments need to have comprehensive revenue policies and ensure that people pay taxes properly and regularly. They also need to ensure that programs to reduce poverty are effective. Particularly, they should track all pro-poor spending and provide access to services that will enable people to escape poverty.

In its efforts to end extreme poverty, Bangladesh got many of the basics right. Bangladesh set an example of impressive record of economic growth and investments in people despite many internal and external challenges. This helped to lift millions of people out of poverty. Inclusive development is about to ensure development of standard of living and economic sustainability of every single individual in the country as well as 'leaving no one behind' which the motto of the Government of Bangladesh. It is recognized that economic growth is not sufficient for reducing poverty rate. Hence, the Government of Bangladesh has given priority to inclusive and sustainable development rather than economic growth only. Accordingly, the Five Year Plans and other national documents have put emphasis on efficient allocation and utilization public funds for better public services delivery based on sound PFM system.

Qualitative analysis (based on limited quantitative information from secondary sources) indicates that the enhancement of fiscal transparency, particularly budget transparency, has contributed positively in reducing both national poverty and extreme poverty in Bangladesh because initiatives related to poverty reduction can now be better tracked and monitored. This, in turn, not only ensures efficient allocation and utilization of resources but also helps to identify which works and which does not. Nonetheless, various assessments indicate that there is room for improvement in terms of transparency, public participation, scrutiny and oversight. 


\section{References}

Ali, E., 2017, Measuring the Redistributive Impact of Taxes and Transfers in the Presence of Re-ranking, Chapter 3 in Commitment to Equity Handbook. A Guide to Estimating the Impact of Fiscal Policy on Inequality and Poverty (Brookings Institution Press and CEQ Institute, Tulane University)

Ali, E., Lustig, N. and Aranda, R., 2017, Analytical Foundations: Measuring the Redistributive Impact of Taxes and Transfers, Chapter 2 in Commitment to Equity Handbook. A Guide to Estimating the Impact of Fiscal Policy on Inequality and Poverty (Brookings Institution Press and CEQ Institute, Tulane University)

Baldrich, J., 2005, Fiscal Transparency and Economic Performance, Available at http://www.aaep.org.ar/anales/works/works2005/baldrich.pdf

Bangladesh Bank, 2017, Annual Report 2015 - 2016

Bangladesh Bureau of Statistics, Government of Bangladesh, 2017, Household Income and Expenditure Survey 2016

Bangladesh Bureau of Statistics, Government of Bangladesh, 2011, Household Income and Expenditure Survey 2010

Bangladesh Bureau of Statistics, Government of Bangladesh, 2006, Bangladesh Poverty Maps (Zila, Upazila) 2005

Glennerster and Yongseok, 2003, Is Transparency Good for You, and Can the IMF Help? IMF Working Paper 03/132

Hameed, 2005, Fiscal Transparency and Economic Outcomes, IMF Working Paper 05/255

International Budget Partnership, 2016, Open Budget Index

International Budget Partnership, 2014, Open Budget Index

International Budget Partnership, 2010, Open Budget Index

International Budget Partnership, 2006, Open Budget Index

International Monetary Fund, 2007, Manual on Fiscal Transparency

International Monetary Fund, 2005a, The Standards and Codes Initiative - Is It Effective? And How Can It Be Improved?

International Monetary Fund, 2005b, Key Trends in Implementation of the Fund's Transparency Policy

International Monetary Fund, 2003, Assessing and Promoting Fiscal Transparency: a Report on Progress

International Monetary Fund, 2002, Standards and Codes - Their Impact on Sovereign Ratings

Kuteesa, F. et al., 2006, Uganda: A Decade of Budget Reform and Poverty Reduction, OECD Journal of Budgeting, 6(2): 1-25

Lustig, N., 2017, Fiscal Policy, Income Redistribution and Poverty Reduction in Low and Middle Income Countries, Working Paper 448, Centre for Global Development

Mason, E. S. 1960, The Role of Government in Economic Development, The American Economic Review, Vol. 50, No. 2, Papers and Proceedings of the Seventy-second Annual Meeting of the American Economic Association (May, 1960), pp. 636-641

Ministry of Finance, Government of Bangladesh, 2017, Bangladesh Economic Review

Ministry of Finance, Government of Bangladesh, 2017, Budget Speech 2017-2018 (plus other supplementary)

Ministry of Finance, Government of Bangladesh, 2017, Child Budget 2017-2018

Ministry of Finance, Government of Bangladesh, 2017, Gender Budgeting Report 2017-2018

Ministry of Finance, Government of Bangladesh, 2017, Medium-Term Budget1 ary Framework (MTBF) 2017-18 to 2019-20

Parnini, S. N., 2017, The Role of Government in Economic Development: A Comparative Study between Bangladesh and South Korea, Journal of Public Administration and Governance

Parry, T., 2007, The Role of Fiscal Transparency in Sustaining Growth and Stability in Latin America, IMF Working Paper 07/220 
Planning Commission, Government of Bangladesh, 2011, $6^{\text {th }}$ Five Year Plan FY2011 - FY2015 - Accelerating Growth and Reducing Poverty, Strategic Directions and Policy Framework

Planning Commission, Government of Bangladesh, 2016, $7^{\text {th }}$ Five Year Plan FY2016 - FY2O2O - Accelerating Growth, Empowering Citizens

Planning Commission, Government of Bangladesh, 2012, Perspective Plan of Bangladesh (2010-2021): Making Vision 2021 a Reality

The World Bank, 2005, Creating Fiscal Space for Poverty Reduction in Ecuador - A Fiscal Management and Public Expenditure Review 